\title{
ROLE OF MAST CELLS IN LEPROSY- A STUDY OF 62 CASES
}

\author{
Shivani Jindal', Mridu Manjari², Monika Girdhar ${ }^{3}$
}

${ }^{1}$ Assistant Professor, Department of Pathology, Adesh Medical College and Hospital, Shahbad, Kurukshetra, Haryana.

2 Professor and HOD, Department of Pathology, SGRD, Amritsar, Punjab.

${ }^{3}$ Associate Professor, Department of Pathology, Maharaja Agrasen Medical College, Agroha, (Hisar), Haryana.

\section{ABSTRACT}

\section{BACKGROUND}

Mast cells have received little attention in leprosy, but evidence linking them with delayed-type hypersensitivity reactions raises the possibility that they may be of some importance in leprosy.

\section{MATERIALS AND METHODS}

The present study is a descriptive study. Biopsies obtained from the clinically diagnosed patients were fixed in $10 \%$ formalin, processed and three sections of $6 \mu \mathrm{m}$ thickness were cut and stained with routine Haematoxylin and Eosin (Culling, Allison, Barr 1985), by Toluidine Blue and by Modified Thionin/Acridine Orange method.

\section{RESULTS}

Mean number of mast cells were more in lepromatous leprosy than in tuberculoid.

\section{CONCLUSION}

This study reflects the variety of immunological reactions occurring in leprosy and the role of mast cells in these immunological phenomena.

\section{KEYWORDS}

Mast Cells, Metachromatic, Lepromatous, Tuberculoid.

HOW TO CITE THIS ARTICLE: Jindal S, Manjari M, Girdhar M. Role of mast cells in leprosy- A study of 62 cases. J. Evolution Med. Dent. Sci. 2017;6(74):5328-5331, DOI: 10.14260/Jemds/2017/1157

\section{BACKGROUND}

Mast cells are inflammatory mediators that play a central role in inflammatory and immediate allergic reactions. They settle in connective tissue and do not circulate in blood. These were first described by Ehrlich in 1873 by their ability to stain metachromatically with basic aniline dyes like Toluidine blue, thionin and Giemsa. ${ }^{1}$ These are larger than eosinophils and basophils and are found in tissues along the nerves and blood vessels. These are bone marrow derived and express a variety of phenotypic factors. They act as reservoirs of inflammatory mediators and rapidly synthesise others on activation like histamine, proteases, chemotactic factors and metabolites of arachidonic acid. These mediators act on the vasculature, smooth muscle, connective tissue, mucous glands and inflammatory cells. By virtue of the various mediators, mast cells help in immunity. They participate in inflammatory reactions like urticaria and angioedema and also in some chronic conditions like appendicitis. ${ }^{2}$

Leprosy is a chronic granulomatous disease affecting principally the nerves and the skin, caused by M. leprae, which was demonstrated in 1873 by Armauer Hansen of Norway. Although much improved since the last 20 yrs., the knowledge of the pathogenesis and treatment of the disease continues to evolve. ${ }^{3}$ Even with proper MDT, the consequent

Financial or Other, Competing Interest: None.

Submission 28-08-2017, Peer Review 10-09-2017,

Acceptance 12-09-2017, Published 18-09-2017.

Corresponding Author:

Dr. Shivani Jindal,

\#B8/102, Nirmal Chhaya

Towers, VIP Road, Zirakpur, Punjab.

E-mail: shivanijindal2015@gmail.com

DOI: $10.14260 /$ jemds $/ 2017 / 1157$ sensory and motor damage results in disabilities and deformities. The portal of entry of the organism is not known, but the skin and upper respiratory tract, particularly the nasal mucosa are the probable sites. Droplet infection is the most likely mode of transmission, however, cases of inoculation, infection have been recorded. The incubation period is 6 months to 40 yrs., or longer. ${ }^{4} \mathrm{M}$. leprae is an obligate intracellular bacillus ( 0.3 to $1 \mu \mathrm{m}$ long) and is acid fast. It is a straight or slightly curved rod that is present singly or in small or large bundles or globi. The organism cannot be grown in vitro, but can be grown in the foot pads of mice and in the nine-banded armadillo. It has a generation time of 12 to 14 days. ${ }^{5}$ The organism has an affinity for macrophages or Schwann cells where it replicates slowly and induces cell mediated immune reaction. As a result, swelling occurs in the in the perineurium which causes ischaemia, fibrosis and axonal death. Body tries to rid itself of the organism activating macrophages and also mast cells leading to tissue destruction and regeneration. This host response determines the type of leprosy the patient develops. At one end of the spectrum, there is lepromatous leprosy (LL) where there is specific failure of cellular immunity to $M$. leprae and the organism proliferates without hindrance. At the other end is the tuberculoid leprosy (TT), where there is a good immune response and the bacteriological index is low. Therefore, in tuberculoid leprosy, morphologically there are well developed epithelioid cell granulomas, often around neurovascular bundles. These also contain mast cells and are present in the papillary dermis. Langhans giant cells are common. However, in borderline tuberculoid (BT), granulomas are apparent but giant cells might be absent. Fewer lymphocytes and mast cells are seen as compared to TT. In borderline-borderline (BB), the granulomas are diffuse 
and lack giant cells. In borderline lepromatous (BL), smaller granulomas with some foamy change are seen, along with numerous lymphocytes and mast cells. In LL, a diffuse infiltrate of foamy macrophages and mast cells is present in the dermis below a subepidermal Grenz zone. An enormous no. of AFB develop within the foamy macrophages, singly or in clumps called globi.

Thus, mast cells can be used as an important indicator of the patient immunity in leprosy; as such these are found more in lepromatous than tuberculoid leprosy. This study highlights the same and these findings can be used to subtype the leprosy cases.

\section{MATERIALS AND METHODS}

The present study was a time limited descriptive study and designed to include maximum number of patients that come to the Department of Dermatology and are clinically diagnosed as leprosy. It was evaluated over a time of two years from June 2006 to December 2008. The study consisted of 62 cases diagnosed clinically as leprosy. The sample size was selected conveniently. New untreated leprosy cases were selected regardless of their age, sex, socioeconomic status and occupation. Biopsies were taken for the histopathological diagnosis and sent to the Department of Pathology. The biopsies were fixed in $10 \%$ formalin, processed and three sections of $6 \mu \mathrm{m}$ thickness each were cut. One was stained with routine Haematoxylin and Eosin (Culling, Allison, Barr 1985). ${ }^{6}$ Diagnosis was confirmed on these sections as leprosy. The Ridley and Jopling Classification was followed in histopathological diagnosis. ${ }^{7}$ Then the rest two sections were stained by Toluidine Blue ${ }^{8}$ and by Modified Thionin/Acridine Orange method. ${ }^{9}$ Mast cells were observed under the microscope and counted as no. of cells/HPF. On an average at least 10 fields were counted in each section examined. Then, the mean no. of mast cells was calculated by dividing the total no. of cells counted with the no. of fields counted. A repeat biopsy after treatment of six months was obtained wherever possible.

\section{RESULTS}

Leprosy is a spectral disease, the clinical and histopathological features of which depend upon the level of the cellular immune response to Mycobacterium leprae. ${ }^{(7,8)}$ In this study, it was seen to be more common in particular age groups especially the third or fourth decade of life, while none were seen under the age group of ten years. Age of the patients varied from 10-78 years with majority in the age group of 21-46 years. While only one patient was under the age group of 10 years, those who were above the age of 60 years were 5 in number. $45.2 \%$ of the patients were seen to be in the third decade of life. Majority of the patients were male $(80.6 \%)$ with a male to female ratio 4.1:1.

Most of the cases presented as hypoaesthetic patches in the extremities while in $14.5 \%$ cases trunk was involved. Another $16.1 \%$ presented with the involvement of the head and neck and the same percentage of cases showed widespread involvement of the whole body.

Borderline tuberculoid was the most common type histologically followed by tuberculoid leprosy. Total no. of cases of both borderline lepromatous and lepromatous together were 7 and 3 cases each of indeterminate leprosy and ENL reactions were also reported.
No. of cells were counted as /HPF. Maximum no. of cells were observed in lepromatous types of leprosy while the least no. was seen in the indeterminate leprosy (Table 1). These were seen around the granulomas in tuberculoid leprosy, perivascular and periadnexal in indeterminate and mainly in the papillary dermis in the lepromatous type. Another finding was a sharp decline in the mean no. of cells in lepromatous cases after treatment (Table 2). In 19 cases, a repeat biopsy was taken after a treatment of minimum 6 months, and it was seen that mast cells decreased after treatment from a mean of 47 cells/sq. mm. before treatment to 14 cells/sq. mm. after treatment. This can be used as an important indicator of the compliance and response to treatment.

It was also seen that the mean no. of mast cells in ENL was less than the non-reactional group. The visualisation of mast cells was much better in Toluidine blue as compared to thionin/acridine orange method. While thionin showed mainly degranulated cells, Toluidine blue showed both intact as well degranulated cells. Another observation made was that the no. of these cells was more in AFB positive cases while the no. was less in AFB negative cases.

\begin{tabular}{|c|c|c|c|}
\hline \multirow{2}{*}{$\begin{array}{c}\text { Type of } \\
\text { Leprosy }\end{array}$} & \multirow{2}{*}{ No. of Cases } & \multicolumn{2}{|c|}{$\begin{array}{c}\text { Mean No. of Mast Cells } \\
\text { before Treatment }\end{array}$} \\
\cline { 2 - 4 } & & TB & TH/AO \\
\hline B.B & 3 & $38 \pm 17.2$ & $31 \pm 15.2$ \\
\hline B.T & 32 & $37 \pm 38.5$ & $26 \pm 14.9$ \\
\hline T.T & 15 & $38 \pm 24.7$ & $30 \pm 21.2$ \\
\hline B.L & 2 & $40 \pm 21.2$ & $34 \pm 19.3$ \\
\hline L.L & 2 & $47 \pm 30.8$ & $41 \pm 27.4$ \\
\hline I.L & 3 & $27 \pm 5$ & $21 \pm 1.4$ \\
\hline B.B $\rightarrow$ B.L & 1 & $15 \pm 0$ & $12 \pm 0$ \\
\hline B.L $\rightarrow$ B.T & 1 & $33 \pm 0$ & $27 \pm 0$ \\
\hline ENL & 3 & $32 \pm 8.7$ & $27 \pm 8$ \\
\hline Total & $\mathbf{6 2}$ & $\mathbf{3 9} \pm \mathbf{2 1 . 2}$ & $\mathbf{3 2} \pm \mathbf{1 8 . 0}$ \\
\hline \multicolumn{3}{|c|}{ Table 1 } \\
\hline
\end{tabular}

\begin{tabular}{|c|c|c|c|}
\hline \multirow{2}{*}{ Type of Leprosy } & \multirow{2}{*}{ No. of Cases } & \multicolumn{2}{|c|}{$\begin{array}{c}\text { Mean No. of Mast Cells } \\
\text { after Treatment }\end{array}$} \\
\cline { 2 - 4 } & & TB & TH/AO \\
\hline B.B & - & - & - \\
\hline B.T & 9 & $30 \pm 0$ & $28 \pm 0$ \\
\hline T.T & 2 & $30 \pm 33.9$ & $28 \pm 31.1$ \\
\hline B.L & 4 & $37 \pm 27.8$ & $30 \pm 21.6$ \\
\hline L.L & 2 & $14 \pm 5.6$ & $9 \pm 3.6$ \\
\hline I.L & 1 & $33 \pm 15.5$ & $27 \pm 14.6$ \\
\hline B.B $\rightarrow$ B.L & - & - & - \\
\hline B.L $\rightarrow$ B.T & - & - & - \\
\hline ENL & 1 & $18 \pm 0$ & $15 \pm 0$ \\
\hline Total & $\mathbf{1 9}$ & $\mathbf{3 0} \pm \mathbf{1 9 . 0}$ & $\mathbf{2 4} \pm \mathbf{1 6 . 4}$ \\
\hline \multicolumn{4}{|c|}{ Table 2 } \\
\hline
\end{tabular}




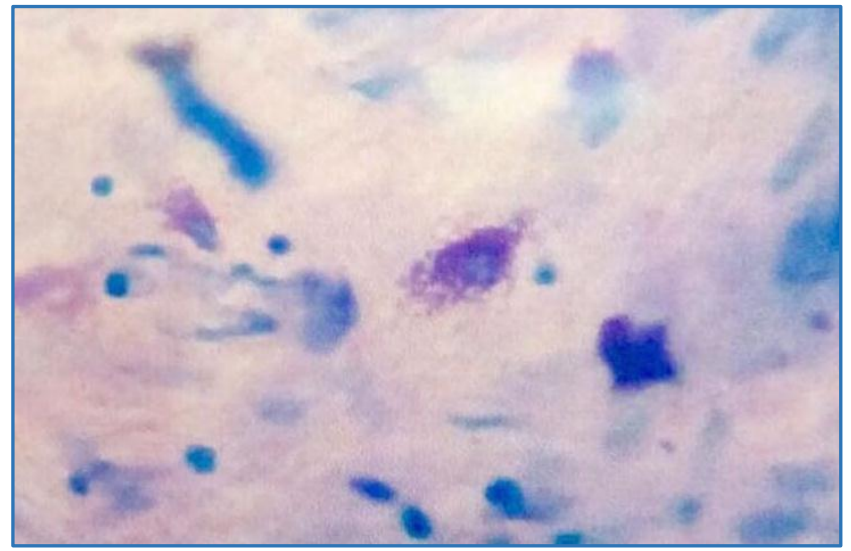

Figure 1. A Degranulating Mast Cell in a Section Stained by Toluidine Blue (400X)

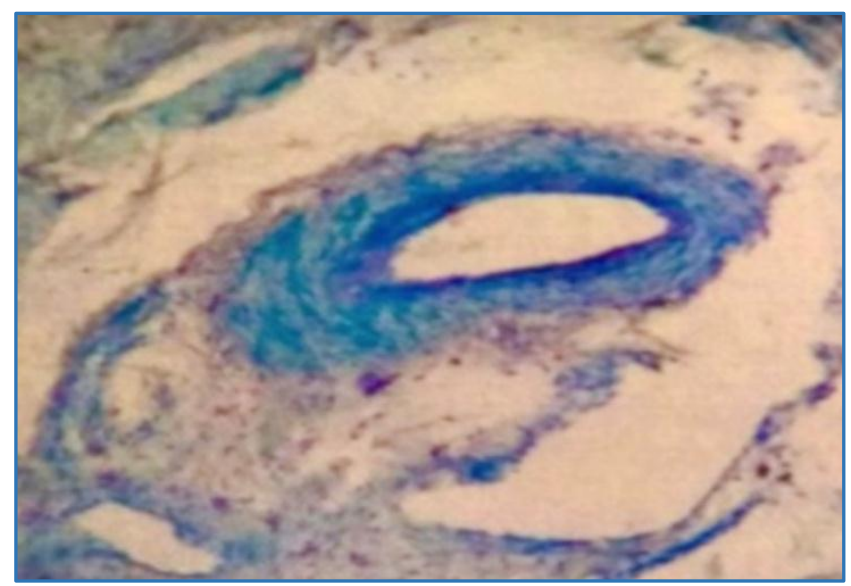

Figure 2. Mast Cells seen in a Perivascular Arrangement in Toluidine Blue (100X)

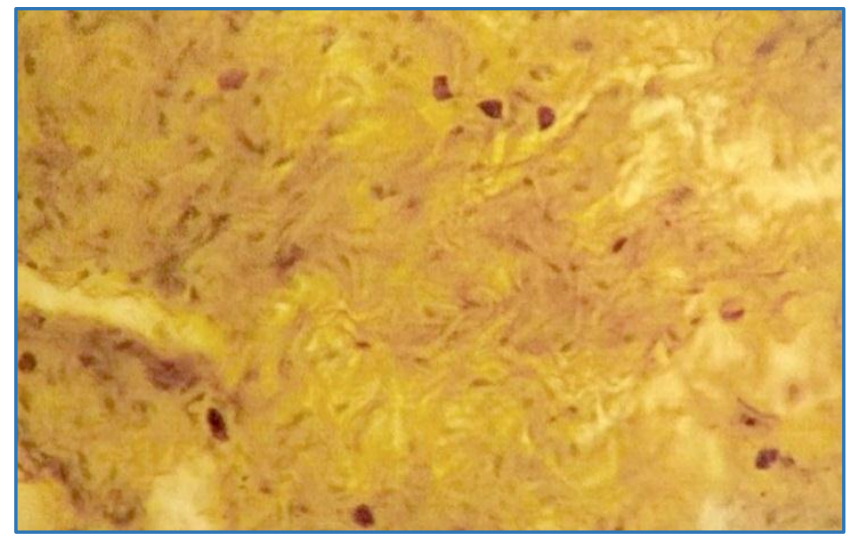

Figure 3. Mast Cells in Modified Thionin/ Acridine Orange Stain (100X)

\section{DISCUSSION}

Leprosy is a chronic granulomatous pathology caused by Mycobacterium leprae, and affects mainly the skin and the nervous system. The response of the body to the bacterium depends on the immune system of the individual. This results in the development of the different types of leprosy from the tuberculoid end of the spectrum to the lepromatous end with borderline forms in between. ${ }^{10}$ Leprosy is characterised histologically by granuloma formation. The type of granuloma depends upon the cellular-immune response of the host to the organism. ${ }^{6}$ Usual cells which participate in the granuloma formation are epithelioid cells, macrophages and lymphocytes but mast cells also have been observed in such lesions. Various inflammatory mediators play a role in the development of the leprotic patches, consisting of lymphocytes, mast cells and foamy macrophages. ${ }^{11}$ Mast cells have received little attention in leprosy, but evidence linking them with delayed-type hypersensitivity reactions raises the possibility that they may be of some importance in leprosy, in both the nonreactional and reactional states. They release many cytokines like TNF, interleukins, prostaglandins and more, which mediate in the development of the pathological process. The change in the average mast cell number in nonreactional leprosy and leprosy reactions may indicate the important role of mast cells in dynamic changes in the cellmediated immune response in leprosy and leprosy reactions. ${ }^{12}$ We used this mast cell property to determine the mast cell number in skin sections of leprosy and leprosy reactions. The results provide an insight into the role of mast cells as part of the immunologic reaction in leprosy.

Mast cell no. depicts the immunity of the patient, thus it can differentiate various types of leprosy. In a study conducted by Naik et al, high mast cell count was seen in polar forms, both tuberculoid and lepromatous. In tuberculoid leprosy, the cells were concentrated around nerve fibres. ${ }^{13}$ Similar results were seen in the present study as the no. of mast cells in lepromatous leprosy were 47 cells/sq. mm and the cells were seen mainly in the papillary dermis. However, in tuberculoid leprosy the mean no. of mast cells was far less and these were seen mainly around the granulomata and the nerve fibres. In biopsy specimens taken from the edge of established lesions, the density of mast cells within the granulomata was considerably higher than that in the intervening dermis. ${ }^{14}$

The routine haematoxylin- eosin stain cannot identify mast cells. Various staining procedures have been devised for the proper visualisation of mast cells. Toluidine blue is the most common stain employed for the same, the others being thionin/acridine, Bismarck brown, and Alcian blue. Victor et al observed that thionin/acridine orange is a good stain to visualise mast cells and it is easy to prepare, low dye concentration is needed, gives consistent results and is an easy to perform technique. ${ }^{9}$ In contrast, in the present study, it was seen that Toluidine blue is a much better stain than thionine/acridine orange method, because even intact cells were seen, while in thionin/acridine only degranulated cells could be visualised.

Mast cells play an important role not only in immediate hypersensitivity reactions, but also in delayed hypersensitivity reactions. ${ }^{15}$ These are activated by cytokines such as Interleukin-3 (IL-3) and IL-4 produced by the activated $\mathrm{T}$ cells. ${ }^{16}$ The $\mathrm{T}$-cell-mediated immune response plays a major part in leprosy. Various studies document the predominance of mast cells in lepromatous leprosy in comparison to tuberculoid leprosy. ${ }^{17,18,19} \mathrm{~A}$ study showing the cytokine patterns and T-cell subsets in leprosy shows that in lepromatous lesions, typical Th-2 cytokines are high, one of which is $\mathrm{IL}-4.20$ On the other hand, reactive $\mathrm{T}$ cells from tuberculoid patients were of the Th-1 phenotype, and these cells produce undetectable levels of IL-4. ${ }^{21}$ Mast cells have been known to induce variety of cytokines, such as TNF- $\alpha$, IL1, IL-4, IL-5, IL-6, and GM-CSF. Bagwan et al found that mast cells in LL type were denser than TT type. All the above findings were consistent with the results of our study. ${ }^{22}$ 
The mean no. of mast cells decreased after treatment in the present study. This suggests a good response to chemotherapy and one is likely to believe that the number would reduce after treatment. However, some studies have reported no significant difference. This was probably due to long life span of mast cells, which ranges from weeks to months. ${ }^{23}$

Lepromatous leprosy as such has more no. of mast cells as compared to the tuberculoid leprosy. This has been reported by other researchers as well.18,19

Increased vascularity and changes in the endothelial cells are more pronounced in lepromatous leprosy. This may be the reason behind more no. of mast cells. In multibacillary leprosy there's increased production of IL-3, IL-4, and GMCSF by the CD8+ and Th2 population of CD4+ cells. This might again lead to intense presence of mast cells in such cases. ${ }^{20,24}$

\section{CONCLUSION}

The study reflects the variety of immunological reactions occurring in leprosy and the role of mast cells in these immunological phenomena. In this study, there were limitations such as research design and method of identifying mast cell levels that could affect the study results. Further studies are needed to study the role of mast cells in both reactional and non-reactional leprosy and especially how this property can be utilised for the diagnosis of leprosy. Drugs that target mast cells can also be employed to modify the treatment and have better results especially in drug resistant cases.

\section{REFERENCES}

[1] Ehrlich P. Thesis. Leipzig University, Beiträge zur Theorie und Praxis der histologischen Färbung. 1878:6-17.

[2] Weber S, Krasagakes-Kruger S, Grabbe J, et al. Mast cells. Int J Dermatol 1995;34(1):1-10.

[3] Lastória JC, de Abreu MA. Leprosy: review of the epidemiological, clinical and etiopathogenic aspectspart 1. An Bras Dermatol 2014;89(2):205-18.

[4] Patterson JW. Bacterial and Rickettsial infections. Chap-23. In: Patterson JW. edr. 4th edn. Philadelphia, PA: Elsevier Churchill Livingstone 2016: p. 658.

[5] Jopling WH, McDougall AC. Handbook of leprosy. $5^{\text {th }}$ edn. Delhi: CBS Publishers and Distributors 1996:1053.

[6] Allison RT, Barr WT, Culling CFA. Haematoxylin and its counterstains. Cellular pathology technique. $4^{\text {th }}$ edn. London: Butterworth-Heinemann 1985.

[7] Ridley DS, Jopling WH. Classification of leprosy according to immunity: A five group system. Int J Lepr Other Mycobact Dis 1966;34(3):255-73.
[8] Luna L. Manual of histologic staining methods from the AFIP. $3^{\text {rd }}$ edn. New York: McGraw-Hill 1968:162-3.

[9] Victor R, Ravindranath R, Padmalatha K, et al. A modified thionin acridine-orange stain for mast cells. Indian Journal of Pathology \& Microbiology 2004;47(2):168-9.

[10] Moorthy BN, Kumar P, Chatura KR, et al. Histopathological correlation of skin biopsies in leprosy. Ind J Dermatol Venereol Leprol 2001;67(6):299-301.

[11] Sengupta U. Cell-mediated immunity in leprosy: an update. Int J Lepr Other Mycobact Dis 1993;61(3):43954.

[12] Mahaisavariya P, Jiamton S, Manonukul J, et al. Mast cells in leprosy and leprosy reaction. International Journal of Dermatology 2000;39(4):274-7.

[13] Naik R, Pai MR, Bantwal PB, et al. Study of mast cells in non-neoplastic skin lesions. Indian J Pathol Microbiol 2003;46(2):173-5.

[14] Cree IA, Coghill G, Beck JS. Mast cells in leprosy skin lesions. J Clin Pathol 1990;43(3):196-200.

[15] Galli SJ, Dvorak AM. What do mast cells have to do with delayed hypersensitivity? Lab Invest 1984;50(4):365-8.

[16] Cotran KS, Kumar V, Robbins S. Diseases of immunity. Robbins pathologic basis of disease. $4^{\text {th }}$ edn. Philadelphia: W B Saunders Company., 1989:163-237.

[17] Aroni K, Kontochristopoulos G, Liossi A, et al. An investigation of mast cells in two basic leprosy groups. Int J Lepr other Mycobact Dis 1993;61(4):634-5.

[18] Rav SD, Pratap VK, Sharma NK, et al. Mast cell in leprosy. Indian J Lepr 1990;62:467-72.

[19] van Hale HM, Turkel SB, Rea TH. Dermal ultrastructure in leprosy. Arch Pathol Lab Med 1984;108(5):383-6.

[20] Yamamura M, Uyemura K, Deans RJ, et al. Defining protective responses to pathogens: cytokine profiles in leprosy lesions. Science 1991;254(5029):277-9.

[21] Haanen JBAG, de Wall MR, Res PCM, et al. Selection of a human $\mathrm{T}$ helper type 1-like $\mathrm{T}$ cell subset by mycobacteria. J Exp Med 1991;174(3):583-92.

[22] Bagwan IN, Khandekar MM, Kadam P, et al. A study of mast cells in granulomatous lesions of skin, with special emphasis on leprosy. Indian $\mathrm{J}$ Lepr 2004;76(1):31-7.

[23] Jayalakshmi P, Lian TK. Mast cells in lepromatous leprosy. International Journal of Leprosy 1991;63(20): 291-3.

[24] Ramos T, Zalcberg-Quintana I, Appelberg R, et al. Thelper subpopulations and the immune spectrum of leprosy. Int J Lepr 1989;57:73-81. 